\title{
Perceived Government Autonomy, Economic Evaluations, and Political Support During the Eurozone Crisis
}

\begin{abstract}
The Eurozone crisis and resulting economic interventions present a particular manifestation of the dilemma between globalisation and national democracy, one in which supranational involvement led to an unprecedented reduction in democratic governance. This has been linked to an erosion in support for the domestic political system, but the precise mechanism is still debated. This paper tests two mechanisms proposed in the recent literature: firstly, that citizens perceived that their domestic system's autonomy was constrained by the economic interventions, which led citizens to reduce their support for the domestic system; secondly, that the decline was due to worsening economic evaluations. This paper tests these arguments together at the individual level for the first time using a multilevel analysis of European Election Study data, and replicates the results with a case study of Portugal. The analysis finds no support for the autonomy argument, but instead points to the crucial role of economic evaluations.
\end{abstract}

\author{
Daniel Devine \\ University of Southampton \\ Department of Politics and International Relations, \\ University Road \\ Southampton, \\ SO17 1BJ, \\ United Kingdom \\ Email: D.J.Devine@Soton.ac.uk
}

Manuscript accepted to West European Politics. Please cite the published version available at https://doi.org/10.1080/01402382.2019.1675130. 


\section{Introduction}

What is the impact of supranational involvement in domestic politics on citizens' support for their national democratic system? And, most importantly, what is the mechanism underlying the relationship? This paper answers these questions. A key concern in the existing broader literature is that the growing influence of regulatory actors beyond the domestic political sphere leads to a hollowing out of national-level democratic procedures, resulting in greater levels of political disaffection with national democracy (Rodrik, 2011; Kriesi, 2014; Mair, 2007, 2013). This is especially prevalent with regard to European integration. Scharpf (1996) for instance argued that 'the democratic autonomy of political decisions is progressively weakened' from European integration resulting in 'general political disaffection and alienation'. Likewise, DeBardeleben and Hurrelmann (2007) linked the loss of autonomy in the context of European integration to a 'profound disaffection' with domestic democratic institutions.

External actors defining the policy room to manoeuvre of domestic politics is not new (Gourevitch, 1978; Katzenstein, 1985; Hellwig, 2001; Kayser, 2007). However, the Eurozone crisis of 2008-2014 was one in which 'external actors define[d] the room for manoeuvre of national politics in many European countries to an unprecedented extent' (Armingeon and Guthmann, 2014, p. 425). During this period, Ireland and countries in Southern Europe experienced a set of structural reform programmes requested by international and supranational organisations. The memorandums of understanding between the EU, IMF and national governments meant that future policy programmes were largely decided beyond the reach of popular influence and democratic choice. Ultimately, public political will and elections 'no longer served as mechanisms [of] policy change' (Ruiz-Rufino and Alonso, 2017, p. 320). This led to claims that throughout Europe there was a 'democracy without choice', 'democratic void', or ‘democratic impotence' (Sánchez-Cuenca, 2017).

Current empirical research on the effects of the Eurozone crisis, economic interventions and support for the domestic system concludes in line with the theoretical literature that this hollowing out of democratic procedures has reduced citizens' support for their national system, defined as support for how the democratic political system works in practice (Polavieja, 2013; Armingeon and Guthmann, 2014; Armingeon, Guthmann 
and Weisstanner, 2016; Ruiz-Rufino and Alonso, 2017; Schraff and Schimmelfenig, 2019; Drakos et al, 2019). Yet the precise mechanism is debated. One proposed mechanism is that citizens care about their government's autonomy to decide on policy, and reduce their political support if they believe their 'national government's autonomy is compromised by external impositions' (Ruiz-Rufino and Alonso, 2017, p. 320). Key in this account is that citizens reduce support for their domestic system if they conclude that the policy room to manoeuvre of their national governments is constrained. In this sense, perceptions of political autonomy matter in the formation of political support, and citizens evaluate their domestic system in relation to the international environment. However, existing research is conducted using country-level indicators for the influence of external actors and aggregated public opinion measures, leaving 'uncharted territory on the micro-level mechanisms' (Schraff and Schimmelfennig, 2019, p.19). This link speaks to the broader research gap on the effects of supranational integration on mass politics which is Concerned with individual level mechanisms but often omits individual level analysis?

This article explores this uncharted territory. Specifically, it puts to the test two dominant hypotheses in recent literature. The first follows this discussion and argues that when citizens attribute the loss of policy manoeuvrability to external actors, they reduce their support for the domestic political system. The second hypothesis posits the competing explanation that the loss of support is due to economic factors, specifically individuals' subjective economic evaluations. Using European Election Study data collected in 2009 and 2014, and a new analysis of Portuguese data from 2012, I find no evidence for the 'autonomy' hypothesis. On the contrary, in countries ${ }^{1}$ where we would most expect a negative effect - Greece, Portugal, Italy and Cyprus there is a statistically significant positive effect: those who attribute the 'loss of manoeuvrability' to external actors are more supportive of their domestic system. Instead, the results provide considerable support for the hypothesis that the link between interventions and political support is subjective economic evaluations.

This contributes to the literature on the impact of supranational governance on mass politics in several ways. Theoretically, I build from the existing literature in developing a general model for potential pathways through which economic interventions specifically impact citizens' support for their domestic system. This builds on existing research by developing more clearly the theoretical causal mechanisms, which have so 
far been theoretically under-specified. Conceptually, it innovates within this work by developing and operationalising the mechanism of perceived constraint at the individual level by drawing on the globalisation literature. Finally, empirically the paper contributes the first analysis of the relationship between economic interventions, perceived constraint and citizen support at the individual level, filling a key gap in understanding the dynamics of mass politics through the Eurozone crisis and supranational integration more generally.

The next section develops a model of the pathways through which economic interventions affect citizen support, reviews the existing literature and presents the hypotheses. It then goes on to discuss the data, methods, and results, before concluding with a discussion of the results and wider relevance of the paper.

\section{Theory: Economic Interventions and Political Support}

This section situates the current study in a broader framework by developing a model of the different causal pathways through which economic interventions have been argued to influence citizen support for their domestic system. This takes it as a starting point that the literature has established that interventions negatively impact political support. $^{2}$ The subsequent pathways outlined in figure 1 , indicated by the solid and dashed lines, indicate different causal mechanisms through which interventions might affect individual level attitudes. For expository purposes and following recent work on this topic (Foster and Frieden, 2017; Schraff and Schimmelfennig, 2019), I treat these as competing explanations, but in the Appendix I explore the possibility that they are complementary (finding no evidence that they are). I will first address the two pathways depicted by the dashed lines before developing the main mechanism this paper examines. 


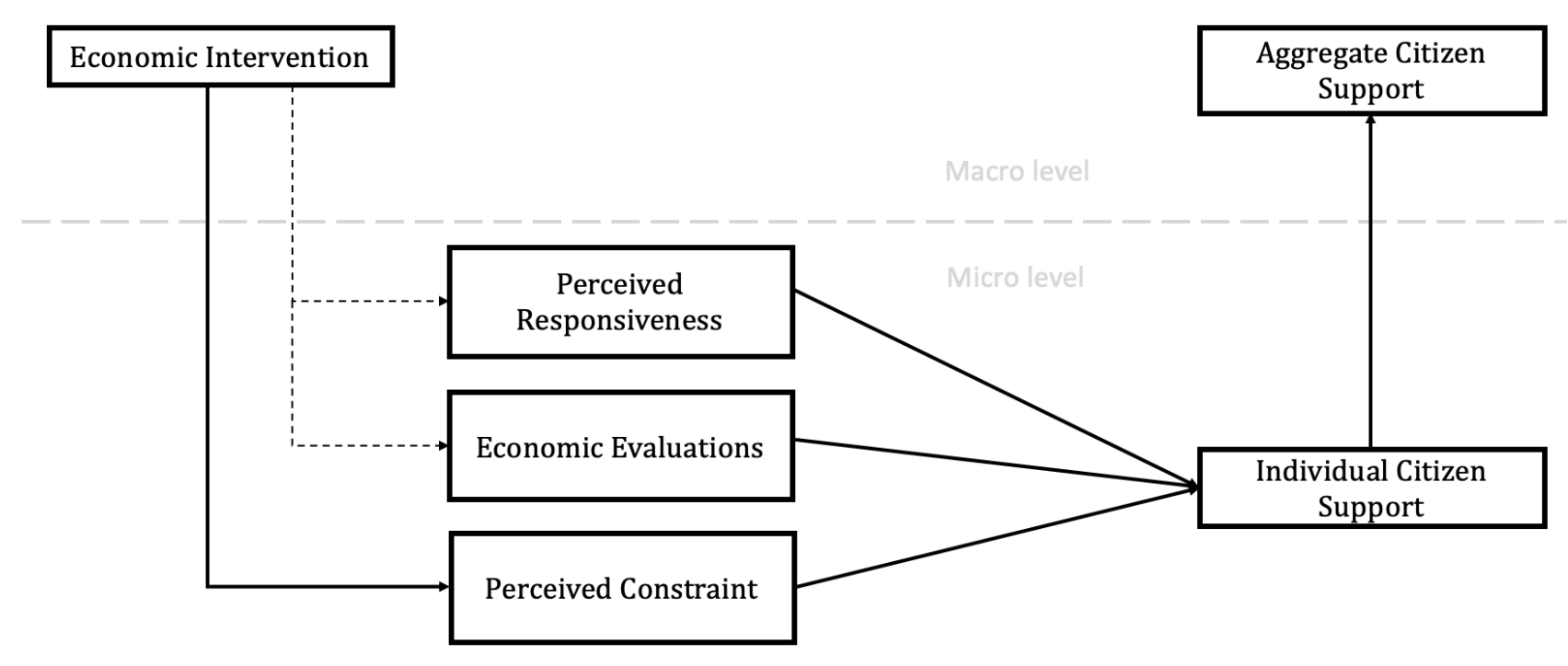

Figure 1: Causal pathways from intervention to political support

Perceptions of economic conditions are the dominant explanation for variation in political support in general, and are the primary explanations for the decline in support over the economic crisis (Drakos et al, 2019; Morlino and Quaranta, 2016; Quaranta and Martini, 2017; Foster and Frieden, 2017; Hetherington, 1998; Ross, 2004). In this pathway, what matters is the role that interventions play in individuals updating their economic beliefs; the intervention signals that economic conditions are extremely poor, and people update their (negative) beliefs about domestic economic performance, which has repercussions for political support. Whilst the specific role of interventions in impacting economic evaluations has not been explored, the role of economic evaluations in forming system support is widely documented across countries (Norris, 2011; van Ham, Thomassen, Aarts and Andeweg, 2017; Stimson, 2004). An important qualification to this is that existing research shows that subjective economic evaluations exert a larger and more robust effect than objective economic conditions (van der Meer, 2018).

An additional potential pathway in the literature, which has received less attention, is that interventions limit the responsiveness of domestic governments, which reduces citizen support (Torcal, 2014). In this case, citizens do not perceive their government as constrained by international actors, but rather only that it is no longer responsive to their needs. The mechanism of responsiveness is one that is common within the literature on explaining political support, tapping into the 'input' determinants of 
political support rather than the economic-driven 'output' determinants (Torcal, 2014; Brandenburg and Johns, 2014). An important clarification to stress here is that external interventions may have been the causal mechanism leading to a lack of responsiveness, but that it is the lack of domestic responsiveness that matters for citizens and not the lack of autonomy vis-a-vis an external actor. Whilst this and perceived constraint are closely related, the key mechanism is different. Citizens can recognise that political actors are not responsive to their demands, without recognising that they are constrained by external actors. In other words, the mechanism is not through perceived constraints on autonomy.

This paper primarily aims at examining the validity of the mechanism depicted by the solid arrow, between perceived constraint and political support. The theoretical argument linking them is that a lack of autonomy signals a lack of democratic choice, both for a government to respond to a mandate and for citizens to choose amongst a legitimate set of choices. That citizens have some democratic choice over policies is a bedrock of even the most minimalist conceptions of democracy (Riker, 1982; Przeworski, 2010; Downs, 1957). Without choice between policy, the democratic process is reduced to 'ratify[ing] choices made elsewhere' (Przeworski, 2010, p.117; Ruiz-Rufino and Alonso, 2017). The context under study here is an example of this 'democracy without choice' (SánchezCuenca, 2017). Since political support is concerned with 'the level of support for how the democratic regime works in practice' the undermining of a core prerequisite for democratic governance may logically lead to a reduction in this support (Linde and Ekman, 2003). A contention is that voters did indeed have choice over policy: in the wake of the Eurozone crisis, numerous parties offered a rejection of the bailout policy programmes which voters could choose from and mobilise around. However, there are two arguments against this. Firstly, it needs to be a meaningful and effective choice which could be enacted when in government; it is important that governments can act on this mandate, not just for citizens to choose amongst a set of nominal choices. Greece's Syriza is a clear example of this. Secondly, academic work has shown that countries that experienced intervention actually had lower levels of citizen-party congruence (Traber et al, 2018) and that many parties depoliticised the European issue (Turnbull-Dugarte, 2019).

The empirical literature linking the decline in citizen support during the Eurozone crisis with political autonomy began relatively recently, but has expanded rapidly. 
Polavieja (2013) argued that the incapacity of governments to manoeuvre within the constraints of the Eurozone provided an additional penalty on satisfaction with democracy. Building on this, Armingeon and Guthmann (2014) explored the hypothesis that external actors imposing policy, operationalised as IMF conditionality, led to an independent negative effect on satisfaction with democracy (SWD) beyond economic harm. They find, using time-series-cross-sectional analysis, that conditionality led to a reduction in both democratic satisfaction and trust in parliament. In their words, 'citizen support for national democracy drops as people attribute the loss of political manoeuvrability to these external actors', though they do not test the mechanism specifically (Armingeon and Guthmann, 2014, p. 425). Advancing this argument later, Armingeon et al. (2016) isolated the effect of economic adjustment using the synthetic control method on four cases, likewise arguing that the imposition of policy in the Eurozone's periphery led to a loss of democratic legitimacy.

Ruiz-Rufino and Alonso (2017) deepened this argument both empirically and theoretically. Using a difference-in-difference analysis, they argue that it was not about objective constraint with regard to being in the Eurozone, since this could not explain why SWD even increased in other Eurozone countries and remained largely stable during European integration. Rather, they argue that explicit interventions in Southern European countries and Ireland marked a 'learning process', where citizens in those countries updated their beliefs about their government's autonomy. Following Armingeon and Guthmann (2014), Ruiz-Rufino and Alonso (2017, p. 320) argue that citizens' support declines 'because their [country's] policy autonomy is compromised'. According to them, this explains the larger decline in intervened-in countries than would be expected otherwise.

In the most recent contribution to this debate, Schraff and Schimmelfennig (2019) provide an analysis using the generalised synthetic control method, which builds directly on Armingeon et al (2016) and Ruiz-Rufino and Alonso (2017). They show that whilst the bailouts did cause a decrease in democratic satisfaction, this vanished after six years. They also find that the effect is much weaker than previous estimates, and that there is significant between country variation: it had almost no negative effects in Ireland and Portugal, but considerable effects in Spain and Greece. They ultimately conclude that economic policy outcomes matter more for political support than the interventions and subsequent infringements on the democratic process. 
Whilst the literature convincingly and rigorously shows that interventions causally led to a decline in citizens' support for their domestic system, there is no prior research testing the proposed mechanism at the individual level: that citizens' subjective beliefs about the autonomy of their domestic system led to a change in political support. The current literature, relying on objective measures of autonomy, cannot make the empirical case of the individual perception of autonomy impacting citizen support: it is equally possible that these objective, country-level measures work through other individual-level mechanisms. Previous research has tested two ends of these causal chains between interventions and political support but has not directly studied the intervening mechanisms (cf. Torcal, 2014). Schraff and Schimmelfennig (2019) note this weakness in their analysis as 'uncharted territory' in the debate; uncharted territory which this paper explores. This is moreover a critical omission given its wider relevance for the literature on the effect of international integration on political behaviour (Scharpf, 1996; Vowles and Xezonakis, 2016; Steiner, 2016; Häusermann, Kurer and Wüest, 2018). This analysis is therefore a timely contribution to this debate.

To sum up this discussion, the following two hypotheses are posited. ${ }^{3}$ The focus in this paper is on $\mathrm{H}_{1}$, whilst $\mathrm{H}_{2}$ provides an alternative mechanism which explains the decline in political support and is consistent with existing literature on the Eurozone crisis and political support more generally.

$\boldsymbol{H}_{1}$ : Higher levels of perceived constraint reduce political support

$\boldsymbol{H}_{2}$ : Worse economic evaluations reduce political support

\section{Data and Methods}

The primary data used to test these hypotheses comes from the European Election Study surveys conducted in 2009 and 2014, which contains all countries which are members of the European Union. As I will describe, this is the only cross-national data set to my knowledge that contains the chosen measures to construct the independent variable of perceived autonomy. In addition, it is conveniently timed just before economic interventions - and the peak of the crisis - and after countries had experienced 
interventions and, in the case of Greece, were due to leave conditionality. Whilst the downside of this is that the data is not placed directly either side of interventions, as would be the ideal, there is no available data set which fulfils this criterion.

I operationalise the key independent variable, perceived political autonomy, as relative responsibility attribution for economic conditions between the domestic government and European Union. In lieu of direct survey questions about the authority government has over certain policies vis-a-vis some external constraint, it is a widely used proxy within similar work on the effects of globalisation on mass politics; as Hellwig, Ringsmuth and Freeman (2008, p. 857) argue, 'causal attribution is the key to understanding how citizens perceive their government's room to manoeuvre'. Putting the proxy to experimental test, Kosmidis (2018) conducted a survey experiment in Greece in 2014, showing how priming respondents on the room to manoeuvre in economic policy shifted responsibility attributions away from the domestic government. In other words, individuals who were primed to believe the Greek government was more constrained also provided it with less responsibility. This has also been shown in observational studies in Latin America and Western Europe (Alcañiz and Hellwig, 2011; Hellwig, 2014; Murphy, 2017; Duch and Stevenson, 2008). During the Eurozone crisis, a lack of autonomy via interventions has been seen to 'shift the responsibility' for the policy packages (Alonso and Ruiz-Rufino, 2018). Whilst issues with this measurement are recognised, the weight of existing research, including experimental evidence from the same region and year under study here, indicates that it is causally related to actual perceptions of the autonomy of governments and a fair proxy. Nonetheless, I provide a range of robustness tests in the Appendix, interacting it with, for instance, economic evaluations and views on EU unification (Hobolt and Tilley, 2014b; Wilson and Hobolt, 2015; Hobolt and Tilley, 2014a).

The precise measure is derived from two questions. The questions can be illustrated via this example for British respondents:

"Now I would like to ask you some questions about how much responsibility the British government and the European Union have for some of the things going on in Britain. Of course, you may think that neither is responsible. First, thinking about the economy, how responsible is the British government for economic conditions in Britain? Please indicate your views 
using any number on a scale from 0 to 10, where 0 means "no responsibility" and 10 means "full responsibility."

And what about the European Union, how responsible is the EU for economic conditions in Britain?"

Since I am interested in relative responsibility between the two bodies, I follow Hobolt and Tilley (2014b) in subtracting the EU attribution from the national government attribution, which results in a 'net' score running from -10 to +10 , where -10 indicates that the member state is entirely responsible and +10 that the $\mathrm{EU}$ is entirely responsible. It is this unique benefit of being able to derive relative responsibility that makes the EES the most ideal data set available. In reality, $72 \%$ of observations fall within $+/-3$ of the mean value; just $1.3 \%$ of observations are at the upper end of the scale $(5+)$. Because of this, I follow Lobo and Lewis-Beck (2012) and dichotomise the variable to equal 1 if the $\mathrm{EU}$ is seen as more responsible than the domestic state and 0 if the domestic state is equal or more responsible than the EU. I ran the same models, presented in the Appendix, with the continuous indicator and the results are substantively identical.

To some extent, this measurement relies on respondents being knowledgeable enough about the EU to provide responsibility assessments relative to their national government. Ruiz-Rufino and Alonso (2017) have shown how knowledge about the EU, as well as interest in politics, increased sharply during the Eurozone crisis. Whilst there is no doubt that respondents extrapolate their views on their national system to the European level (Harteveld et al, 2013), evidenced by the high correlation between the two variables, this is why the subtracted measure is more useful than the raw measures. The separate indicators are in danger of instead capturing how much responsibility the respondent thinks there is to 'go round' rather than the relative responsibility between the two bodies (even if this is, as in a plurality of cases, an equal amount).

To test the second hypothesis, I use indicators for both retrospective and prospective economic evaluations. The questions ask the respondent, respectively, how they think the economy is compared to 12 months ago, and how it will be over the next 12 months. The respondents can choose between five categories (excluding don't know), from the economy is/will be 'a lot better' through to 'a lot worse'. This too is not without problems. Subjective economic perceptions are not always related to objective economic 
conditions, and are prone to voter rationalisation and endogeneity with other attitudes, like trust (see for example Tilley and Hobolt, 2014b). It should be made clear that this is therefore not measuring necessarily accurate perceptions of what the economy is like. It is however comforting to note that economic voting - voting based on retrospective evaluations of the economy - remained stable throughout the crisis even in countries that experienced intervention, suggesting that extreme dissatisfaction and economic turmoil did not disrupt this relationship (Talving, 2018).

To operationalise citizen political support for their domestic system, the dependent variable, I use binary indicators for SWD and trust in the country's parliament. This is convention within the political support literature (Ruiz-Rufino and Alonso, 2017; Armingeon and Guthmann, 2014; Armingeon et al., 2016; Torcal, 2014; Norris, 2011; Pharr and Putnam, 2000). Unfortunately, neither are available in both 2009 and 2014. In 2009, I use SWD, and in 2014 I use trust in the country's parliament. As Armingeon and Guthmann (2014) argue, whilst support is a multidimensional concept, these two measures address both the general working of democracy, as in the definition used by Linde and Ekman (2003), as well as attitudes towards the core institution of democracy, the parliament. ${ }^{4}$ Although they both tap various aspects of support, and the substantive meaning may differ between institutions and individuals (Canache, Mondak and Seligson, 2001), there is evidence that both are meaningful and comparable indicators of general support for domestic, governing institutions (Marien, 2011; Zmerli and Hooghe, 2011; Ferrin and Kriesi, 2016; Norris, 2011).

I use a range of control variables at the individual and country levels. Along with demographics, I also control for whether the respondent believes EU unification has gone too far or not far enough and whether the individual is a partisan of the incumbent government, since they predict both political support and relative responsibility attribution (Hobolt and Tilley, 2014a). At the country level, I control for four variables used in previous literature. To control for 'objective' constraint on government autonomy I control for Eurozone membership, how long the country has been in the $\mathrm{EU}$, and interest rates (as a summary variable for economic distress and international pressure) (Polavieja, 2013; Armingeon et al., 2016; Armingeon and Ceka, 2013; Hix, 2003). ${ }^{5}$ Since it is a strong predictor of political support, I also control for how long a country has been a democracy measured as the uninterrupted time that a country has been a democracy as determined by the Polity IV data set (Armingeon and Guthmann, 
2014; Dahlberg, Linde and Holmberg, 2015; Cordero and Simón, 2016; De Vries, 2018). A full codebook for all variables is in the Appendix.

For the modelling strategy, I use all EU countries. Because of this clustering and the dependent variable is binary, I use a multilevel logistic model. ${ }^{6}$ Since I expect that the effect of perceived autonomy will be different between countries, I also impose a random slope on the key independent variable, which allows a coefficient in each cluster. ${ }^{7}$ Additional methodological approaches, such as country fixed effects models, are in the Appendix and do not substantively differ from the results presented here.

\section{Results}

The explanatory analysis proceeds chronologically in two steps, beginning with the 2009 data. Table 2 presents the results from this analysis. For clarity, I present only the coefficients for key variables. Full models, including stepwise inclusion of demographic and attitudinal controls, are in the Appendix. Country-level variables are included step-wise.

An initial appreciation of the results shows no significant effect for perceived constraint, and this does not change across models, rejecting $\mathrm{H}_{1}$. Prospective and retrospective economic evaluations have a powerful negative effect on the dependent variable, supporting $\mathrm{H}_{2}$. Being a partisan of the incumbent exerts a statistically significant positive effect. Overall, the initial results from 2009 provide a rebuttal to the perceived political economy argument, and points instead to an important role of economic evaluations. The country-level variables also provide little evidence of this argument. Even interest rates, the variable used to identify effects of external economic pressure, are rendered insignificant once the length of time a country has been a democracy is controlled for. 
Table 1: Logistic multilevel regression of the European Election Study (2009)

\begin{tabular}{|c|c|c|c|c|}
\hline & (1) & $(2)$ & $(3)$ & (4) \\
\hline \multicolumn{5}{|l|}{ Individual-level } \\
\hline EU Responsibility & $\begin{array}{c}-0.113 \\
(0.0741)\end{array}$ & $\begin{array}{c}-0.113 \\
(0.0738)\end{array}$ & $\begin{array}{c}-0.111 \\
(0.0757)\end{array}$ & $\begin{array}{c}-0.111 \\
(0.0756)\end{array}$ \\
\hline Retrospective Economy & $\begin{array}{c}-0.235^{* * *} \\
(0.0207)\end{array}$ & $\begin{array}{c}-0.235^{* * *} \\
(0.0207)\end{array}$ & $\begin{array}{c}-0.236^{* * *} \\
(0.0210)\end{array}$ & $\begin{array}{c}-0.237^{* * *} \\
(0.0210)\end{array}$ \\
\hline Prospective Economy & $\begin{array}{c}-0.296^{* * *} \\
(0.0172)\end{array}$ & $\begin{array}{c}-0.296^{* * *} \\
(0.0172)\end{array}$ & $\begin{array}{c}-0.287^{* * *} \\
(0.0176)\end{array}$ & $\begin{array}{c}-0.287^{* * *} \\
(0.0176)\end{array}$ \\
\hline Incumbent Party ID & $\begin{array}{c}0.579^{* * *} \\
(0.0423)\end{array}$ & $\begin{array}{c}0.579 * * * \\
(0.0423)\end{array}$ & $\begin{array}{c}0.584^{* * *} \\
(0.0429)\end{array}$ & $\begin{array}{c}0.584^{* * *} \\
(0.0429)\end{array}$ \\
\hline Demographic Controls & $\checkmark$ & $\checkmark$ & $\checkmark$ & $\checkmark$ \\
\hline $\begin{array}{l}\text { Attitudinal Controls } \\
\text { Country-level }\end{array}$ & $\checkmark$ & $\checkmark$ & $\checkmark$ & $\checkmark$ \\
\hline Eurozone & $\begin{array}{c}0.00295 \\
(0.413)\end{array}$ & $\begin{array}{l}-0.331 \\
(0.376)\end{array}$ & $\begin{array}{l}-0.363 \\
(0.343)\end{array}$ & $\begin{array}{l}-0.334 \\
(0.286)\end{array}$ \\
\hline Time in EU & & $\begin{array}{c}0.0266^{* * *} \\
(0.00897)\end{array}$ & $\begin{array}{c}0.0157^{*} \\
(0.00950)\end{array}$ & $\begin{array}{c}-0.00828 \\
(0.0107)\end{array}$ \\
\hline Interest Rates & & & $\begin{array}{c}-0.157^{* * *} \\
(0.0597)\end{array}$ & $\begin{array}{l}-0.0756 \\
(0.0553)\end{array}$ \\
\hline Time as Democracy & & & & $\begin{array}{c}0.0358^{* * *} \\
(0.0107)\end{array}$ \\
\hline Random Variation & & & & \\
\hline EU Responsibility & $\begin{array}{c}0.082^{* *} \\
(.037)\end{array}$ & $\begin{array}{c}0.080 * * \\
(0.037)\end{array}$ & $\begin{array}{c}0.083^{* *} \\
(0.038)\end{array}$ & $\begin{array}{c}0.082^{* *} \\
(0.038)\end{array}$ \\
\hline Intercept & $\begin{array}{c}0.946^{* * *} \\
(0.261)\end{array}$ & $\begin{array}{c}0.711^{* * *} \\
(0.197)\end{array}$ & $\begin{array}{c}0.566^{* * *} \\
(0.160)\end{array}$ & $\begin{array}{c}0.390 * * * \\
(0.112)\end{array}$ \\
\hline Observations & 17,701 & 17,701 & 17,155 & 17,155 \\
\hline LogLik & -9665 & -9661 & -9312 & -9307 \\
\hline
\end{tabular}

To provide a more robust test of $\mathrm{H}_{1}$, Figure 1 plots the main coefficient of interest from this model in each country on the odds-ratio scale. The effect of perceived autonomy may vary between countries: Polavieja (2013) for instance argues the effect is larger inside the Eurozone than outside of it, whilst Ruiz-Rufino and Alonso (2017) go further and argue that the difference is between countries that have had external 
economic interventions and those that have not. Schraff and Schimmelfennig (2019) also show that the effect is heterogenous. Not least, empirically the random slope coefficient is significant, which suggests there are differing effects within clusters (i.e countries). Since the main coefficient is a grand mean of all countries, this may be hiding between-country variation. The figure reveals interesting results. Contrary to expectations, in the countries that we would most expect to find a negative effect, attributing more responsibility to the EU actually increases satisfaction with democracy; otherwise, there is a null effect in all other countries. In Italy and Portugal, attributing more responsibility to the EU relative to the national government increases the odds of being satisfied with democracy by about 1.4, and in Cyprus by 1.2 (significant at the $10 \%$ level). In most other countries there is no significant effect. 
Figure 2: Random slopes from the analysis in Table 1 (2009)

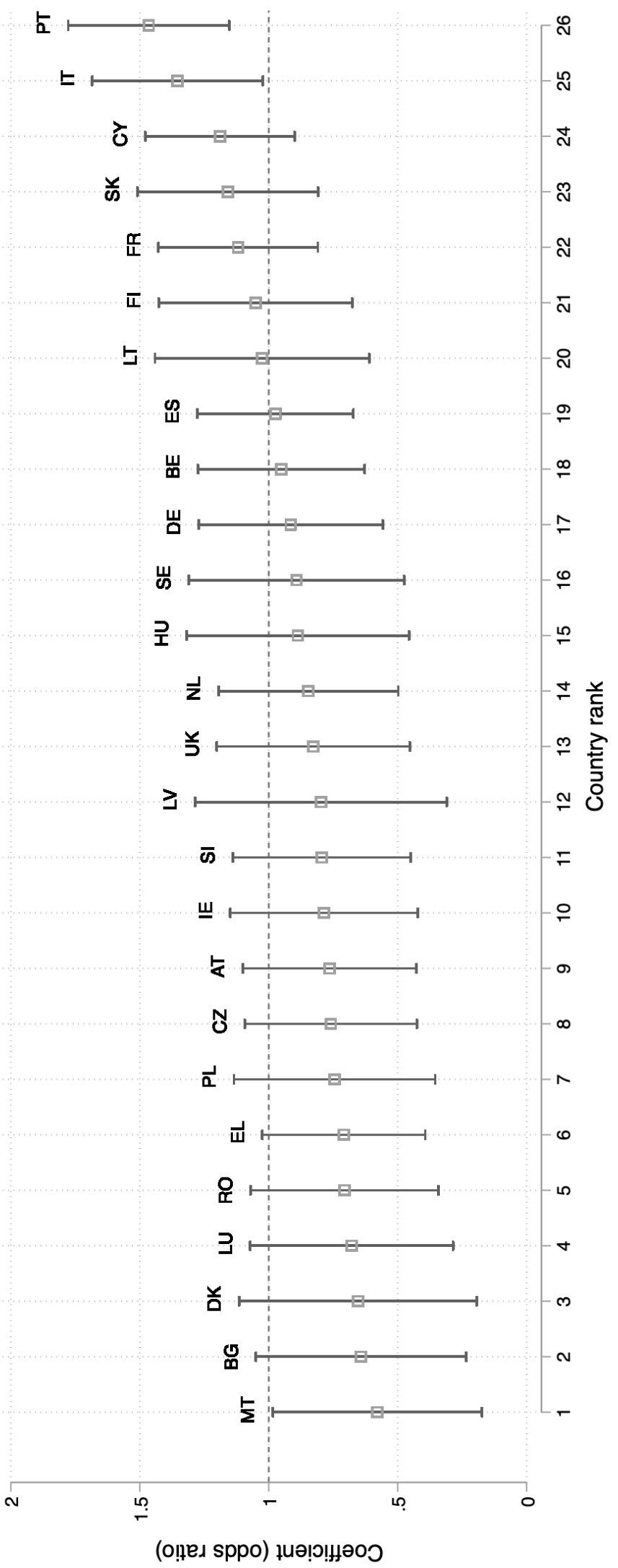


Yet 2009 was before the economic interventions, at which point, the literature argues, citizens updated their beliefs about their governments' levels of autonomy (Ruiz-Rufino and Alonso, 2017). I therefore repeat the analysis on the 2014 data, with results presented in table 2. This is just a year after Cyprus and two years after Spain signed a (partial) Memorandum of Understanding. The coefficient sign has changed direction, but remains insignificant; however, and consistent with the previous analysis and $\mathrm{H}_{2}$, those who have worse economic evaluations are less likely to show support for their political system. For the country level variables, institutional consolidation is highly significant and positive. Yet in this model, the length of time a country has been in the $\mathrm{EU}$ is significant at the $5 \%$ level and negatively signed. In other words, the probability of trusting the national parliament decreases the longer a country is a member of the EU. It is also worth noting the random slope is not significant, suggesting there is less between country variation than in 2009 . 
Table 2: Logistic multilevel regression of the European Election Study (2014)

\begin{tabular}{|c|c|c|c|c|}
\hline & $(1)$ & $(2)$ & (3) & (4) \\
\hline \multicolumn{5}{|l|}{ Individual Level } \\
\hline \multirow[t]{2}{*}{ EU Responsibility } & 0.0312 & 0.0314 & 0.0526 & 0.0529 \\
\hline & $(0.0594)$ & $(0.0595)$ & $(0.0584)$ & $(0.0574)$ \\
\hline \multirow{3}{*}{$\begin{array}{l}\text { Retrospective } \\
\text { Economy }\end{array}$} & $-0.324^{* * *}$ & $-0.324^{* * *}$ & $-0.324^{* * *}$ & $-0.323^{* * *}$ \\
\hline & & & & \\
\hline & $(0.0223)$ & $(0.0223)$ & $(0.0227)$ & $(0.0227)$ \\
\hline \multirow[t]{2}{*}{ Prospective Economy } & $-0.423^{* * *}$ & $-0.423^{* * *}$ & $-0.410^{* * *}$ & $-0.409 * * *$ \\
\hline & $(0.0236)$ & $(0.0236)$ & $(0.0239)$ & $(0.0239)$ \\
\hline \multirow[t]{2}{*}{ Incumbent Party ID } & $0.609^{* * *}$ & $0.610^{* * *}$ & $0.624^{* * *}$ & $0.625^{* * *}$ \\
\hline & $(0.0357)$ & $(0.0357)$ & $(0.0364)$ & $(0.0364)$ \\
\hline Demographic & $\checkmark$ & $\checkmark$ & $\checkmark$ & $\checkmark$ \\
\hline \multicolumn{5}{|l|}{ Controls } \\
\hline Attitudinal Controls & $\checkmark$ & $\checkmark$ & $\checkmark$ & $\checkmark$ \\
\hline \multicolumn{5}{|l|}{ Country level } \\
\hline \multirow[t]{2}{*}{ Eurozone } & 0.212 & -0.0275 & -0.0231 & -0.0590 \\
\hline & $(0.350)$ & $(0.349)$ & $(0.340)$ & $(0.249)$ \\
\hline \multirow[t]{2}{*}{ Time in EU } & & $0.0167^{* *}$ & 0.0101 & $-0.0228^{* *}$ \\
\hline & & $(0.00843)$ & $(0.00931)$ & $(0.00960)$ \\
\hline \multirow[t]{2}{*}{ Interest Rates } & & & $-0.243^{*}$ & -0.0887 \\
\hline & & & $(0.132)$ & $(0.102)$ \\
\hline \multirow[t]{2}{*}{ Time as Democracy } & & & & $0.0432^{* * *}$ \\
\hline & & & & $(0.00891)$ \\
\hline \multicolumn{5}{|l|}{ Random Variation } \\
\hline \multirow[t]{2}{*}{ EU Responsibility } & 0.0465 & 0.0467 & 0.0397 & 0.0367 \\
\hline & $(0.0272)$ & $(0.0273)$ & $(0.0261)$ & $(0.0252)$ \\
\hline \multirow[t]{2}{*}{ Intercept } & $0.740^{* * *}$ & $0.647^{* * *}$ & $0.582^{* * *}$ & $0.306^{* * *}$ \\
\hline & $(0.201)$ & $(0.176)$ & $(0.162)$ & $(0.0861)$ \\
\hline Observations & 20,842 & 20,842 & 20,208 & 20,208 \\
\hline LogLik & -11176 & -11174 & -10814 & -10805 \\
\hline
\end{tabular}

As in the analysis of the 2009 data, the random effects from the model are graphed in figure 2. The pattern stays much the same, but the relationship weakens. Only Greece is now significant beyond the $10 \%$ level. Meanwhile, the other previously significant countries have become indistinguishable from zero. Those countries where we would expect an effect - namely Cyprus and Spain - are not significant. Collectively, the results from the 2009 and 2014 analysis provide a strong rejection of the main 
hypothesis $\left(\mathrm{H}_{1}\right)$ and existing literature on the effects of perceived autonomy on political support during the Eurozone crisis. The results instead provide support for the competing explanation $\left(\mathrm{H}_{2}\right)$ that economic evaluations played a key role in political support during the Eurozone crisis, consistent with much of the literature (Foster and Frieden, 2017). 
Figure 3: Random slopes from the analysis in Table 2 (2014)

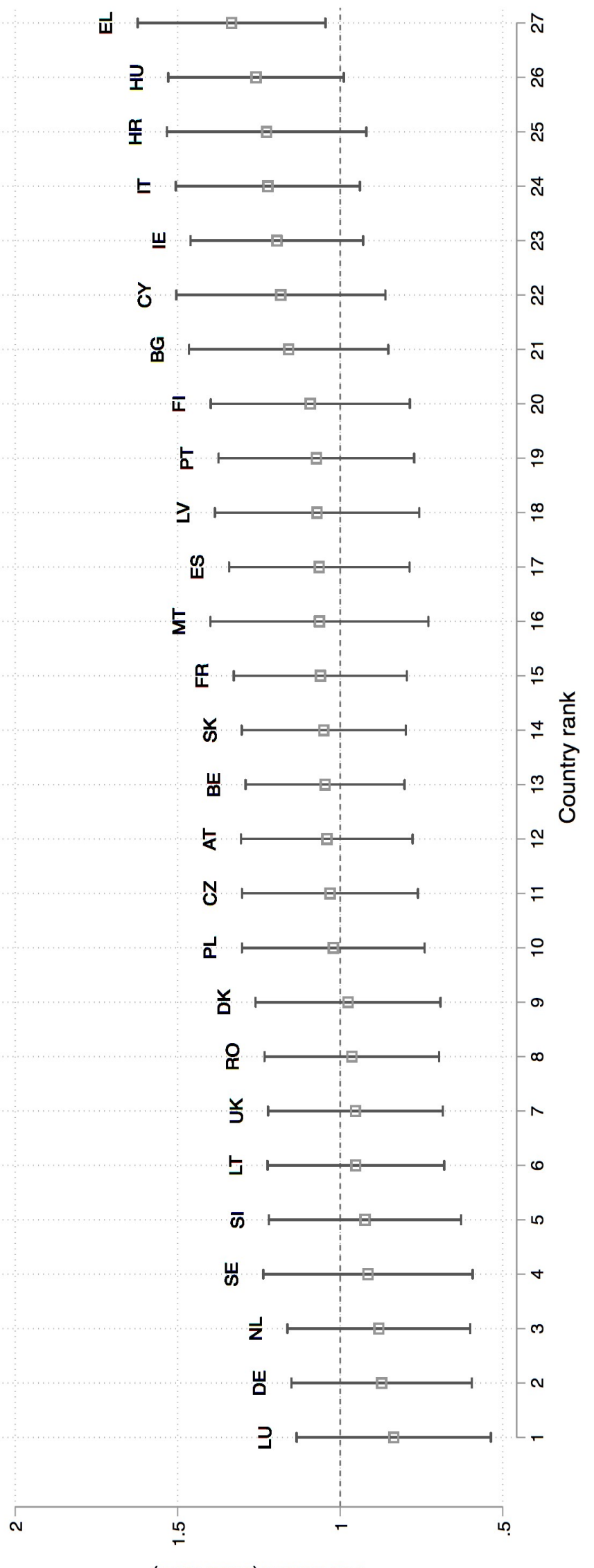

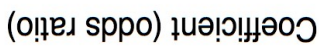




\section{Additional Analyses}

To check the robustness of these results, a series of additional analyses were conducted. Here I repeat the analysis on alternative data, and for clarity describe others which are presented in the Appendix.

For the final analysis, I rely on data from Portugal in 2012.8 The timing is excellent, providing a midway point between the 2009 and 2014 data analysis and just a year after Portugal experienced economic intervention. The data also contains an approximation of the key independent variable, since it asks respondents to rank how much responsibility the Portuguese government and the EU have for the recent economic conditions on a scale of $1-5 .{ }^{9}$ It also asks an identical question on satisfaction with democracy using the same response categories. ${ }^{10}$

Following the main analysis, I create a measure of relative responsibility by subtracting the responsibility attributed to the EU and domestic government and dichotomise the democratic satisfaction indicator. I also control for demographics (sex, age, education, employment status), political interest, support for EU unification, left-right selfpositioning, retrospective economic views and whether the respondent is a partisan of the incumbent government. The results from the model, including both a continuous and binary version of the independent variable, are presented in table 3 . 
Table 3: Robustness Test: Portugal (2012)

\begin{tabular}{|c|c|c|}
\hline & $\begin{array}{c}\text { (1) } \\
\text { Continuous } \\
\text { IV }\end{array}$ & $\begin{array}{c}(2) \\
\text { Binary } \\
\text { IV }\end{array}$ \\
\hline EU Responsibility & $\begin{array}{r}-0.0937 \\
(0.108)\end{array}$ & \\
\hline EU Responsibility & & $\begin{array}{l}-0.223 \\
(0.439)\end{array}$ \\
\hline Gender & $\begin{array}{l}0.0166 \\
(0.23)\end{array}$ & $\begin{array}{l}0.0187 \\
(0.231)\end{array}$ \\
\hline Age & $\begin{array}{l}-2.21 \mathrm{E}-07 \\
(0.00894)\end{array}$ & $\begin{array}{r}-0.000487 \\
(0.00893)\end{array}$ \\
\hline Education & $\begin{array}{l}0.237^{* * *} \\
(0.0772)\end{array}$ & $\begin{array}{c}0.235^{* * *} \\
(0.0771)\end{array}$ \\
\hline Interest & $\begin{array}{l}0.417^{* * *} \\
(0.143)\end{array}$ & $\begin{array}{c}0.415^{* * *} \\
(0.143)\end{array}$ \\
\hline EU Unification & $\begin{array}{l}0.0414 \\
(0.037)\end{array}$ & $\begin{array}{c}0.0438 \\
(0.0369)\end{array}$ \\
\hline Left-Right & $\begin{array}{l}0.106^{*} \\
(0.0631)\end{array}$ & $\begin{array}{l}0.104^{*} \\
(0.063)\end{array}$ \\
\hline Ret. Economy & $\begin{array}{l}0.357^{* * * *} \\
(0.128)\end{array}$ & $\begin{array}{c}0.360^{* * *} \\
(0.129)\end{array}$ \\
\hline $\begin{array}{l}\text { Incumbent Party } \\
\text { ID }\end{array}$ & 0.208 & 0.225 \\
\hline & $(0.327)$ & $(0.325)$ \\
\hline $\begin{array}{l}\text { Employment } \\
\text { Status }\end{array}$ & -0.0507 & -0.0524 \\
\hline Constant & $\begin{array}{l}(0.0439) \\
-5.053^{* * *} \\
(0.892) \\
\end{array}$ & $\begin{array}{c}(0.0438) \\
-5.321^{* * *} \\
(0.835) \\
\end{array}$ \\
\hline Observations & 803 & 803 \\
\hline LogLik & -270.7 & -271 \\
\hline
\end{tabular}

The results are consistent with the previous analyses, rejecting $\mathrm{H}_{1}$ and providing support for the alternative explanation $\mathrm{H}_{2}$. This provides additional evidence closer to the intervention that perceived autonomy was not the causal mechanism at work. In this analysis, as before, economic evaluations provide the greatest predictor. 
Alternative analyses are presented in the Appendix. As in table 3, I firstly try alternative specifications of the dependent and independent variables; for example, using the original continuous predictor and ordinal dependent variable. Whilst the main coefficient does indeed change, the random effects parameters, as in figures 2 and 3 , remain consistent. Since the model specification is complicated, I also run the same regression (without country-level variables) in each country, which essentially produces 28 different models. If the claim is correct, such modelling specification should not greatly change the substantive results. This is indeed the case. Coefficient plots for each country confirm an identical pattern. In a similar vein, I run fixed effects models to remove between-country variation for both the full sample and for the intervenedin countries, which confirms an identical pattern to the models presented. Finally, to be sure that that the results are not a product of individuals attributing interventions to the International Monetary Fund rather than the EU, I run an identical analysis but with responsibility vis-a-vis the IMF. The results are the same as those already presented, suggesting that individuals largely saw them working in tandem.

\section{Discussion}

Recent literature has argued that one explanation for the decline in political support in Europe during the Eurozone crisis is that citizens, particularly those who experienced economic interventions, recognised that their governments lacked autonomy over political decision making. This, it has been argued, means citizens updated their political support on the belief that domestic democratic processes were not working. This essentially empirical argument resonates with a long history of theoretical literature which has argued that ongoing economic integration - into the European Union or wider global economy - limits democratic autonomy which can lead to disaffection and alienation. Thus, the period of the Eurozone crisis acts as a case study for the most intense forms of integration. However, empirical research has been limited to country level indicators for an objective lack of autonomy (such as being under conditionality or within the Eurozone) or from aggregated survey data, which cannot address which individual-level mechanisms are at work (Schraff and Schimmelfennig, 2019). 
This paper has filled this gap. It first refined the potential theoretical pathways through which interventions impact citizens' support for their domestic system, synthesising the multiple causal mechanisms. The paper tested the 'constrained autonomy' mechanism at the individual level for the first time using European Election Study data and replicated the results with additional data from Portugal in 2012. Contrary to the existing literature on the effect of perceived autonomy during the Eurozone crisis, the results provide no evidence that those who perceive a reduced level of autonomy have lower levels of political support. In some cases, it increases support. The paper rather finds evidence in all three analyses for the competing explanation: economic evaluations $\left(\mathrm{H}_{2}\right)$ played a pivotal role in the formation of political support over the crisis, echoing the claim that economic factors are more important 'than the quality of the democratic process' (Schraff and Schimmelfennig, 2019, p.1).

Why might it be that null or opposite effects are found for $\mathrm{H}_{1}$ ? There are multiple possible reasons. The existing literature on globalisation and, in particular, economic voting may provide an answer. In this literature, it has been shown that voters who perceive governments to be constrained by the economy are less likely to punish incumbents for economic performance (Hellwig, 2008); likewise, both economic voting and voter turnout is weaker in countries that are more highly integrated into the global economy (Hellwig and Samuels, 2007; Hellwig, 2001; Marshall and Fisher, 2015; Steiner, 2016). In countries with weaker state capacity and where the private sector or IMF have larger degrees of control over policy, responsibility is likewise shifted to them, exonerating domestic politicians (Alcañiz and Hellwig, 2011). In other words, situations in which the government has less capacity, less responsibility is attributed to them. Alternatively, Larsen et al (2019) show that a bailout in the Netherlands actually increased political support; they argue that citizens rewarded government for acting, even if these policies were potentially harmful. It is not clear if this can be generalised to externally derived bailouts. Genovese et al (2016) do, however, provide evidence that intervention reduced protests in countries which experienced them.

What is the mechanism linking the interventions with a decline in political support? The theoretical framework in figure 1 suggests two alternative pathways. The results in this paper are consistent with a model in which support is driven by economic evaluations. A consideration to begin with is whether the intervention signalled that the economy was worse than individuals had previously believed, or that it was going 
to get much worse; in other words, interventions were a signal which updated economic beliefs and, consequently, political support. A second pathway not tested here is through the responsiveness of the political system. There is strong evidence in general that citizens care about responsiveness. In the case of the intervened-in countries, a lack of responsiveness to public policy preferences may have played a role in the reduction of political support, and this may have been facilitated by the interventions (Turnbull-Dugarte, 2019). In both of these cases, future research should move beyond the two ends of the causal chain and focus on establishing a link between the intervention, these intervening mechanisms, and the outcome.

As always, there are limitations to this paper which should be addressed in future research. The main issue lies in the operationalisation of perceived governmental autonomy as responsibility attribution. This is defensible on theoretical and empirical grounds, but also poses problems. Many responses are clustered in the middle and few at the ends of the scale. This means that many see the EU and their national government as equally responsible or simply generalise their views of the national level to the European level (Harteveld et al, 2013). Whilst this was addressed through subtracting the separate measures from each other (thus resulting in a difference) and dichotomising the variable, it also suggests respondents may not be quite as discriminating when answering the question as we would hope, and may simply see that there is 'more responsibility to go around' for positive or negative outcomes. Nonetheless, as Kosmidis (2018) has shown, this is currently a defensible proxy and the best measure available. Future research should trial alternative ways of measuring this and embed them in regular surveys.

The data is also cross-sectional, and the usual caveats for cross-sectional data apply. This is all that is currently available to test the first hypothesis. However, the argument could be strengthened by a natural experiment (for example, survey data conducted over the course of an intervention) or panel data which could provide further evidence of the two alternative mechanisms delineated in figure 1.

Few attempts have been made to empirically examine the larger concerns about the processes of global and European integration leading to political disaffection, despite long-standing theoretical debate. The Eurozone crisis provides an excellent case study for this literature. By examining two proposed mechanisms in this broader literature, 
this paper suggests that future research should look elsewhere rather than to the mechanism of whether individuals perceive their domestic system as constrained. This is not meant to discourage attention to the issue. The national democratic system is decreasingly the 'locus for the exercise of self-government' (Sánchez-Cuenca, 2017). The consequences of this are currently shaking the European establishment. It is therefore crucial to accurately understand the mechanism linking these political developments with changes at the level of mass politics.

\section{NOTES}

${ }^{1}$ I include here Greece and Ireland in 2010; Portugal, Spain and Italy (though not formally) in 2011; Spain (partial signature) in 2012; and Cyprus in 2013. See also Schraff and Schimmelfennig $(2019$, p.6)

${ }^{2}$ See, in particular, Ruiz-Rufino and Alonso (2017) for an analysis of this

${ }^{3}$ Unfortunately, data is not available to test the 'responsiveness' mechanism.

${ }^{4}$ It is acknowledged that its importance varies on whether the system is more or less presidential in structure, but still remains a valid measure of overall support for the political system

${ }^{5}$ Note that including interest rates excludes Estonia, since data is not available.

6 There is a considerable amount of cross-national variation in the dependent variables; the intracluster correlation for satisfaction with democracy is $24 \%$ and for trust $21 \%$.

${ }^{7}$ For parsimony, additional models within each country (i.e, single level) are presented in the Appendix.

${ }^{8}$ The data is available from: http://er.cies.iscte-iul.pt/en/node/23. A full description of the sampling is available at: http://er.cies.iscte-iul.pt/sites/default/dfiles/Mass\%20Survey\%20Report\%20-\%20FINAL.pdf

9 The exact question wording is: 'In the past few years the economy has been in recession. How responsible, if at all, are each of the following for the poor economic conditions of the past two years? Extremely responsible, Very responsible, moderately responsible, A little responsible, Not at all responsible'

${ }^{10}$ The exact wording is 'On the whole are you very satisfied, fairly satisfied, not very satisfied or not at all satisfied with the way democracy works in Portugal?' 


\section{Funding}

This work was supported by the Economic and Social Research Council South Coast Doctoral Training Partnership under Grant number ES/J500161/1 and through the TrustGov project under Grant number ES/S009809/1

\section{Acknowledgements}

I am extremely grateful to all of those who have discussed with me or read the many permutations of this paper. In no order, I'd like to thank Adriana Bunea, Raimondas Ibenskas, Viktor Valgarðsson, Nicole Watson, Marc Hooghe, Silke Goubin, Ingi Iusmen, Will Jennings, Cal Le Gall, Stephanie Bispo, and Matt Ryan. An early version of this paper was presented at Politicogenetmaal 2018, University of Leiden. I thank the panel participants for their helpful feedback, particularly Wouter Schakel, Armen Hakhverdian and Lisanne de Blok. The anonymous reviewers provided excellent comments which improved the paper substantially.

\section{$\underline{\text { Notes on Contributors }}$}

Daniel Devine is a PhD Candidate in Politics at the University of Southampton, and a Research Fellow on the TrustGov project based at the University of Southampton (www.trustgov.net). $\mathrm{He}$ is interested in the field of political behaviour broadly, and the causes and consequences of political trust and democratic satisfaction in particular. His $\mathrm{PhD}$ thesis focuses on the role of European and global integration in shaping political attitudes. He has previously published in the British Journal of Political Science and The Political Quarterly. [d.j.devine@soton.ac.uk]

Twitter:@DanJDevine 


\section{REFERENCES}

Alcañiz, Isabella, and Timothy Hellwig (2011). 'Who's to Blame? The Distribution of Responsibility in Developing Democracies', British Journal of Political Science, 41:2, 389-411.

Alonso, Sonia, and Rubén Ruiz-Rufino (2018). 'The costs of responsibility for the political establishment of the Eurozone (1999-2015)', Party Politics, Forthcoming.

Armingeon, Klaus, and Besir Ceka. (2013). 'The loss of trust in the European Union during the great recession since 2007: The role of heuristics from the national political system', European Union Politics, 15:1, 82-107.

Armingeon, Klaus. and Kai Guthmann (2014). 'Democracy in crisis? The declining support for national democracy in European countries, 2007-2011', European Journal of Political Research, 53:3, 423-442.

Armingeon, Klaus, Kai Guthmann, and David Weisstanner (2016). 'How the Euro divides the union: The effect of economic adjustment on support for democracy in Europe', Socio-Economic Review, 14:1, 1-26.

Brandenburg, Heinz, and Robert Johns (2014). 'The Declining Representativeness of the British Party System, and Why It Matters', Political Studies, 62:4, 704-725.

Canache, Damarys, Jeffery J. Mondak, and J. and Mitchell A. Seligson (2001). 'Meaning and Measurement in Cross-National Research on Satisfaction with Democracy', Public Opinion Quarterly, 65:4, 506-528.

Cordero, Guillermo. and Pablo Simón (2016). 'Economic Crisis and Support for Democracy in Europe', West European Politics, 39:2, 305-325.

Dahlberg, Stefan, Jonas Linde, and Sören Holmberg (2015). 'Democratic Discontent in Old and New Democracies: Assessing the Importance of Democratic Input and Governmental Output', Political Studies, 63, 18-37.

De Vries, Catherine (2018). Euroscepticism and the Future of European Integration. Oxford: Oxford University Press.

DeBardeleben, Joan, and Achim Hurrelmann (Eds.). (2007). Democratic Dilemmas of Multilevel Governance: Legitimacy, Representation and Accountability in the European Union. Basingstoke: Palgrave Macmillan.

Drakos, Konstantinos, Christos Kallandranis, and Socrates Karidis (2019). 'Determinants of Trust in Institutions in Times of Crisis: Survey-Based Evidence from the European Union: Determinants of Trust in Institutions in times of crisis'. JCMS: Journal of Common Market Studies, Online First.

Duch, Raymond. M, and Randy Stevenson (2008). The Economic Vote: How Political and Economic Institutions Condition Election Results. Cambridge: Cambridge University Press.

Downs, Anthony (1957). An Economic Theory of Democracy. New York: Harper and Row.

Ferrin, Monica. and Hanspeter Kriesi. (Eds.) (2016). How Europeans View and Evaluate Democracy. Oxford: Oxford University Press. 
Foster, Chris. and Jeffery Frieden (2017). 'Crisis of trust: Socio-economic determinants of Europeans' confidence in government'. European Union Politics, 18:4, 511-535.

Genovese, Federica, Gerald Schneider, and Pia Wassmann (2016). 'The Eurotower Strikes Back: Crises, Adjustments, and Europe's Austerity Protests'. Comparative Political Studies, 49:7, 939-967

Gourevitch, Peter, (1978). The Second Image Reversed: The International Sources of Domestic Politics. International Organization, 32:4, 881-912.

Häusermann, Silja, Thomas Kurer, and Bruno Wüest (2018). 'Participation in hard times: How constrained government depresses turnout among the highly educated', West European Politics, 41:2, 448-471.

Hellwig, Timothy (2001). 'Interdependence, Government Constraints, and Economic Voting', The Journal of Politics, 63:4, 1141-1162.

Hellwig, Timothy (2008). 'Globalization, Policy Constraints, and Vote Choice', The Journal of Politics, 70:4, 1128-1141.

Hellwig, Timothy (2014). 'Balancing Demands: The World Economy and the Composition of Policy Preferences', The Journal of Politics, 76:1, 1-14.

Hellwig, Timothy, Eve M. Ringsmuth, and John R. Freeman (2008). 'The American Public and the Room to Maneuver: Responsibility Attributions and Policy Efficacy in an Era of Globalization', International Studies Quarterly, 52:4, 855-880.

Hellwig, Timothy. and David Samuels (2007). 'Voting in Open Economies: The Electoral Consequences of Globalization', Comparative Political Studies, 40:3, 283-306.

Hetherington, Marc J. (1998). 'The Political Relevance of Political Trust', The American Political Science Review, 92:4, 791-808.

Hix, Simon (2003). The End of Democracy in Europe? How the European Union (As Currently Designed) Restricts Political Competition. Unpublished Manuscript. Available at $<$ http://personal.1se.ac.uk/HIX/Working_Papers/Hix-

End_of_Democracy_in_Europe.pdf $>$

Harteveld, Eelco, Tom van der Meer, and Catherine de Vries (2013). 'In Europe we trust? Exploring three logics of trust in the European Union', 14:4, 542-565

Hobolt, Sara. B. and James Tilley (2014a). Blaming Europe? Responsibility without Accountability in the European Union. Oxford: Oxford University Press.

Hobolt, Sara B. and James Tilley (2014b). 'Who's in Charge? How Voters Attribute Responsibility in the European Union', Comparative Political Studies, 47:6, 795-819.

Katzenstein, Peter (1985). Small States in World Markets: Industrial Policy in Europe. Ithaca: Cornell University Press.

Kayser, Mark A. (2007). 'How Domestic Is Domestic Politics? Globalization and Elections', Annual Review of Political Science, 10:1, 341-362.

Kosmidis, Spyros (2018). 'International Constraints and Electoral Decisions: Does the Room to Maneuver Attenuate Economic Voting?', American Journal of Political Science, 62:3, 519-534

Kriesi, Hanspeter (2014). 'The Populist Challenge', West European Politics, 37:2, 361-378. 
Larsen, Erik Gahner, Robert Klemmensen, and Michael Baggesen Kitgaard (2019). 'Bailout or bust? Government evaluations in the wake of a bailout'. European Political Science Review, $11: 2,231-246$

Linde, Jonas, and Joakim Ekman (2003). 'Satisfaction with Democracy: A Note on a Frequently Used Indicator in Comparative Politics', European Journal of Political Research, 42:3, 391-408

Lobo, Marina Costa, and Michael S. Lewis-Beck (2012). 'The integration hypothesis: How the European Union shapes economic voting'. Electoral Studies. Special Symposium: Economic Crisis and Elections: The European Periphery, 31:3, 522-528.

Mair, Peter (2007). 'Political Opposition and the European Union', Government and Opposition, 42:1, 1-17.

Mair, Peter (2013). Ruling the Void: The Hollowing of Western Democracy. London: Verso Books.

Marien, Sofie (2011). 'Measuring Political Trust Across Time and Space'. In M. Hooghe and S. Zmerli (Eds.), Political Trust. Why Context Matters (pp. 13-46). Colchester: ECPR Press.

Marshall, James. and Stephen D. Fisher (2015). 'Compensation or Constraint? How Different Dimensions of Economic Globalization Affect Government Spending and Electoral Turnout'. British Journal of Political Science, 45:2, 353-389.

Morlino, Leonardo, and Mario Quaranta (2016). 'What is the impact of the economic crisis on democracy? Evidence from Europe', International Political Science Review, 37:5, 618633.

Murphy, Justin (2017). 'Mass media and the attribution of blame for globalization'. French Politics, 15:4, 443-459.

Norris, Pippa (2011). Democratic Deficit: Critical Citizens Revisited. Cambridge: Cambridge University Press.

Pharr, Susan. J. and Robert D. Putnam. (Eds.). (2000). Disaffected Democracies: What's Troubling the Trilateral Countries? Princeton: Princeton University Press.

Przeworski, Adam (2010). Democracy and the Limits of Self-Government. Cambridge: Cambridge University Press.

Polavieja, Javier (2013). Economic Crisis, Political Legitimacy, and Social Cohesion. In D. Gallie (Ed.), Economic Crisis, Quality of Work, and Social Integration: The European Experience (pp. 256-278). Oxford: Oxford University Press.

Quaranta, Mario. and Sergio Martini (2017). 'Easy Come, Easy Go? Economic Performance and Satisfaction with Democracy in Southern Europe in the Last Three Decades'. Social Indicators Research, 131:2, 659-680.

Riker, William (1982). Liberalism Against Populism: A Confrontation Between the Theory of Democracy and the Theory of Social Choice. Long Grove: Waveland Press.

Rodrik, Dani (2011). The globalization paradox: Democracy and the future of the world economy. Oxford: Oxford University Press. 
Ross, William (2004). 'The sources of institutional trust in East and West Germany: Civic culture or economic performance?', German Politics, 13:3, 401-418.

Ruiz-Rufino, Rubén, and Sonia Alonso (2017). 'Democracy without choice: Citizens' perceptions of government autonomy during the Eurozone crisis', European Journal of Political Research, 56:2, 320-345.

Sánchez-Cuenca, Ignaco (2017). 'From a Deficit of Democracy to a Technocratic Order: The' Postcrisis Debate on Europe', Annual Review of Political Science, 20:1, 351-369.

Scharpf, Fritz W. (1996). 'Democratic Policy in Europe', European Law Journal, 2:2, 136155.

Schraff, Dominik, and Frank Schimmelfennig (2019). 'Eurozone bailouts and national democracy: Detachment or resilience?' European Union Politics (Forthcoming).

Steiner, Nils. D. (2016). 'Economic globalisation, the perceived room to manoeuvre of national governments, and electoral participation: Evidence from the 2001 British General Election'. Electoral Studies, 41, 118-128.

Stimson, James A. (2004). Tides of Consent: How Public Opinion Shapes American Politics. Cambridge: Cambridge University Press.

Talving, Liisa. (2018). 'Economic voting in Europe: Did the crisis matter?', Comparative European Politics, 16:4, 695-723

Torcal, Mariano (2014). 'The Decline of Political Trust in Spain and Portugal Economic Performance or Political Responsiveness?' American Behavioral Scientist, 58:12, 1542 1567.

Traber, Denise, Nathalie Giger, and Silja Häusermann (2018). 'How economic crises affect political representation: declining party-voter congruence in times of constrained government', West European Politics, 41:5, 1100-1124

Turnbull-Dugarte, Stuart J. (2019). 'The impact of EU intervention on political parties' politicisation of Europe following the financial crisis', West European Politics (Forthcoming).

Van Der Meer, Tom (2018). 'Economic Performance and Political Trust'. In The Oxford Handbook of Social and Political Trust, edited by Eric M. Uslaner. Oxford: Oxford University Press.

van Ham, Carolien, Jacques Thomassen, Kees Aarts. and Rudy Andeweg (Eds.). (2017). Myth and Reality of the Legitimacy Crisis: Explaining Trends and Cross-National Differences in Established Democracies. Oxford: Oxford University Press.

Vowles, Jack and Georgios Xezonakis (2016). Globalization and Domestic Politics: Parties, Elections, and Public Opinion. Oxford: Oxford University Press.

Wilson, Traci. L. and Sara B. Hobolt (2015). 'Allocating Responsibility in Multilevel Government Systems: Voter and Expert Attributions in the European Union'. The Journal of Politics, 77:1, 102-113.

Zmerli, Sonja, and Marc Hooghe (2011). Political Trust: Why Context Matters. Colchester: ECPR Press. 
